\title{
PROBLEMS AND PROSPECTS OF TARGETED PUBLIC DISTRIBUTION SYSTEM IN KARNATAKA-AN OVERVIEW
}

\author{
Dr. Elayaraja K. \\ Faculty, Department of Studies in Economics, Kuvempu University, Jnana Sahyadri, Shankaraghatta - \\ 577 451, Shivamogga, Karnataka, INDIA
}

DOI: 10.46609/IJSSER.2020.v05i11.024 URL: https://doi.org/10.46609/IJSSER.2020.v05i11.024

\begin{abstract}
Targeted Public Distribution System (TPDS) a part of the Poverty Alleviation Programme of Indian Government. This scheme was introduced in 1997. PDS, a rationing instrument, which entitle, households to specific quantities, essential commodities selected and food grains at reasonable prices to BPL, APL and AAY families. The present study focused on the Performance of TPDS in Karnataka in recent years and food security supporting an ambitious new Annabhagya scheme was introduced. The scheme consists of brief information on different aspects of Annabhagya Programme working details. So, these programmes present merits and demerits across the states. It throws light on some Problems suggestions policy measures for its better working in Karnataka.
\end{abstract}

Key words: PDS, TPDS, Food security, Annabhagya Scheme

\section{Introduction}

India is a developing country and most of the people are still living Below Poverty Line, so many programmes were introduced by Government of India during the planning period. Such programmes like poverty alleviation is related to Public distribution System has been most important need for helping poor people of India. Performance of Public Distribution System in recent years working has been very well. Targeted Public distribution system touches the lives of millions of poor people in India. The PDS came into existence as a result of the Bengal famine in 1943 as well as during 1950s and 1960s it worked as a dual mechanism providing price support to producers and at the same time provided food subsidy for consumers. National level food shortages and food price inflation forced the government to generate a surplus of foodgrains during the 1980s and the welfare component of the PDS gained strength. This led to a decline in the incidence of poverty from about 50 percent in the 1960 s to about 30 percent in the 1990s. 
International Journal of Social Science and Economic Research

ISSN: 2455-8834

Volume:05, Issue:11 "November 2020"

The TPDS further liberalized in December 2000 and renamed as Antyodaya Anna Yojana. The poor was further classified as the poorest among the poor under this scheme. Supply deficiency foodgrains is not the only cause of food insecurity but historical evidence shows that famines and food security in India were the result of wrong policy of government. Amartya Sen has pointed it out during the great Bengal famine of 1943. There was no scarcity of foodgrains (Sen, 1999). Public distribution of foodgrains is very essential for removing food insecurity. Taking into consideration the severity, any scheme must efficiently allocate and distribute food for the people at affordable prices. An important component of supply management of needed commodities is the PDS and government provides safety net for the poor on the one hand and fulfils the objectives of growth with justice on the other.

The Public Distribution System involved there are several problems in the implementation and operation of the scheme.

\section{Statement of the Research Problem}

Benefits of Public Distribution system was supposed to reach only the needy, but what is happening otherwise, that there are many bogus cardholders. Similarly, while distributing food grains, it was often reported that, food grains to be distributed, has been diverted to open market. In recent years, lack of administrative policies and management of fair price shops level. There are a large number of problems in implementation and operation of the scheme, so these are all the problems faced under the present PDS (Public Distribution System) in Karnataka.

\section{Importance of the Study}

Public Distribution System, one of the important poverty alleviation programmes in India. This scheme is very helpful to especially poor peoples in India. There is more number of human beings still living Below the Poverty Line. Government of India, recent years passed the Food Security Bill of September 2013. This act says that, the main objective of 75 per cent of rural population and 50 per cent of urban population was included. It gets to the needy people. Karnataka state poverty ratio is presently $26.03 \%$ and in recent years new annabhagya programme was implemented by Karnataka government under the targeted PDS presently effective of work of across the state. This scheme was one of the ambitious programme, with higher subsidy and cheap rate of foodgrains provided to the poor people. So, the targeted Public Distribution System was the important food security programmes. And, this scheme has been more helpful to the needy people in Karnataka. 
International Journal of Social Science and Economic Research

ISSN: 2455-8834

Volume:05, Issue:11 "November 2020"

\section{Methodology}

The study essentially concentrates on secondary data, the main source of secondary data on Public Distribution, Dept. of Food and Civil Supplies Report, Government of India and Karnataka, Food Corporation of India Report and Economic survey, Newspapers, Journals, articles, internet, books and periodicals.

\section{Objectives}

1. To know the performance made by TPDS during recent years in Karnataka.

2. To find problems under the Targeted public Distribution system and necessary suggestions in Karnataka.

\section{Public Distribution System in India}

PDS was introduced during the period of Second World War. The main objective of the TPDS is food grains to poorest families in remote and rural areas. PDS is a poverty alleviation programme and contribute towards the social welfare of the people, supplied essential commodities viz., rice, wheat, sugar, kerosene to the people under the PDS at reasonable prices. It is the primary social welfare and antipoverty programme to the Government of India. In India, there is network of more than 5.27 lakh Fair Price Shops (ration shops) one of the biggest PDS in the world, responsible for distributing more than 160 million families. PDS is currently operated as the joint liability of the State and the Central Government. PDS facing lot of problems in 1992, government introduced a Revamped Public Distribution System (RPDS) to reach poorer households with more varieties and quantities of foodstuff at cheaper rate, but it was not effective in June 1997, a targeted public distribution system TPDS was introduced as part of different schemes for the poor, Antyodaya Anna Yojana (AAY) Mid-day Meals, ICDS in children and food for work scheme. Under this scheme, the poor was further classified as the poorest among the poor and others as living-BPL families since 1997 Targeted PDS is intended to target poor people, amount i.e., spent by the Government should utilize the benefits by purchasing the food grains allotted under the Targeted Scheme.

\section{Karnataka}

In Karnataka, about 62 per cent of the income is derived from agriculture. It is the sixth largest states in India, comprises of 30 districts. Its total land area is 1,91,791 sq.km and accounts for $5.83 \%$ of the total area of the Country as per 2011 report. The Karnataka State has tried to 
International Journal of Social Science and Economic Research

ISSN: 2455-8834

Volume:05, Issue:11 "November 2020"

implement computerization model on a pilot basis in different parts of the State to make PDS more effective.

Most of the works of PDS are done electronically and its details are displayed in the Karnataka PDS centres gateway. Some of the major Schemes for alleviating poverty and ensuring food security are Annabhagya Yojana, Antyodhaya. The agencies that are concerned in Karnataka State are FCI, KFCSC \& TAPCMS in Karnataka, there are 20,372 FPSs out of which 200 are managed by KFCSC, 8896 by Co-operatives and 11,276 are managed by the individual licenses respectively .

\section{Present Status - New Annabhagya Scheme in Karnataka (TPDS)}

Public Distribution System in Karnataka is one of the important schemes to achieve the philosophy of social justice and economic equality in the state. This is one of the significant programmes introduced Annabhagya by Karnataka government working effectively in recent years. It is a revised form of the traditional public distribution system of Karnataka with few vital modifications. The programme was officially launched on $10^{\text {th }} \mathrm{July,} 2013$ by the Honourable chief Minister of Karnataka. In brief, the scheme aims to provide 30 kilograms of rice per family per month at the price of Re.1/kilogram to below poverty line (BPL) families across the state. The programme covers a total of 108.98 lakh priority households. (87 lakh BPL cardholders and 11.35 lakh Antyodaya Anna Yojana (AAY) beneficiaries across the state. Rice will be distributed through a network of 20.778 public distribution system (PDS) shops. A single person family is eligible for 10 kilo rice, a family with two persons will get twenty kilos a family with 3 and more number of persons is eligible for 30 kilo rice eligible beneficiaries in additional commodities iodized salt and palm oil in recent years to distribution of buy from the fair price shops. The state food department collected fingerprints photographs of all ration cardholders and fed the data into a server that links all the machines. To more eliminate fake ration cards, the government has also linked the cards to electricity meter numbers in urban areas and property tax numbers in rural areas. The PDS runs parallel with the market mechanism to provide sustenance and food security to the people for whom food at market prices are beyond their reach.

Identification of BPL beneficiaries : In Karnataka state, at present the family with the income of less than Rs.17000/- in urban areas and Rs. 12000/- rural areas per annum is categorized as BPL family. As in other states rice, wheat, sugar and kerosene oil are distributed through fair price shops to the beneficiaries under the category of BPL APL and AAY and present status is shown for the period 2008-2015.

Padithara Khatari scheme: This is the new scheme, one of the important main functioning under the TPDS Annabhagya scheme work through the fair price shops revised modification 


\section{International Journal of Social Science and Economic Research}

ISSN: $2455-8834$

Volume:05, Issue:11 "November 2020"

segment in recent years. Padithara khatari scheme has been introduced in the state during February -2014.Under this scheme availability of food grains in fair price shops guarantees from $1^{\text {st }}$ of every month card holders can draw food grains from $1^{\text {st }}$ every month till $10^{\text {th }}$ during 8-00 AM to 8-00 PM (excluding lunch hours between 1-00 and 2-00 PM and national holidays). Another rest of the days in the month fair price shops functions between 8-00 to 12-00 AM and 4-00 to 8-00 PM (excluding Tuesday and national holidays). IT guarantees the foodgrains availability from the first of every month. Otherwise, cardholders are entitling for compensation. So this scheme performance is present work satisfaction under annabhagya scheme.

Table 1. The quantity and rate of food grains that is being distributed in the state under Annabhagya Yojana

\begin{tabular}{|c|c|c|c|c|c|c|c|c|c|c|}
\hline \multirow{4}{*}{$\begin{array}{l}\text { Sl. } \\
\text { No. } \\
1\end{array}$} & \multirow{4}{*}{$\begin{array}{c}\begin{array}{c}\text { Category } \\
\text { of ration } \\
\text { cards }\end{array} \\
\text { AAY }\end{array}$} & \multicolumn{4}{|c|}{ Rice } & \multicolumn{3}{|c|}{ Wheat } & \multicolumn{2}{|c|}{ Sugar } \\
\hline & & \multicolumn{3}{|c|}{ Scale of issue (kgs) } & $\begin{array}{c}\text { Rate } \\
\text { per } \\
\text { kg } \\
\text { (Rs.) }\end{array}$ & \multicolumn{2}{|c|}{ Scale of issue (kgs) } & \multirow{2}{*}{$\begin{array}{c}\text { Rate per } \\
\text { kg (Rs.) }\end{array}$} & \multicolumn{2}{|c|}{$\begin{array}{c}\text { Scale of } \\
\text { issue (kgs) }\end{array}$} \\
\hline & & \multicolumn{3}{|c|}{29} & 1.00 & \multicolumn{2}{|c|}{6} & & & \\
\hline & & & $\begin{array}{l}\text { North } \\
\text { Karnataka } \\
\text { Districts }\end{array}$ & $\begin{array}{l}\text { South } \\
\text { Karnataka } \\
\text { Districts }\end{array}$ & & $\begin{array}{l}\text { North } \\
\text { Karnataka } \\
\text { Districts }\end{array}$ & $\begin{array}{l}\text { South } \\
\text { Karnataka } \\
\text { Districts }\end{array}$ & & & \\
\hline \multirow[t]{3}{*}{2} & \multirow[t]{3}{*}{ BPL } & Single person & 6 & 8 & 1.00 & 4 & 2 & 1.00 & 1 & 13.50 \\
\hline & & Two persons & 14 & 16 & & 6 & 4 & & & \\
\hline & & $\begin{array}{l}\text { Three and above } \\
\text { person families }\end{array}$ & 20 & 24 & & 10 & 6 & & & \\
\hline
\end{tabular}

Source: Karnataka Economic Survey 2014-15

The above table shows the category of ration cards and scale of issue of food grains viz., rice, wheat and sugar in kgs at different prices distributed at eligible households. Antyodaya Anna Yojana (AAY) cardholders get 29 kilogram of rice at Rs.1-00. Secondly 6 kilogram of wheat distributed at Rs.1-00 and sugar can be distributed at Rs.13.50 respectively.

In case of BPL cardholders, food grains viz., rice, wheat and sugar distributed in north and south Karnataka districts. In this criteria, firstly $6 \mathrm{kgs}$ of rice can be distributed to single person one family of north Karnataka districts and $8 \mathrm{kgs}$ distributed to two persons related in north Karnataka districts and 14 kilo south Karnataka, 16 kilo distributed to three and above person families in north Karnataka, 20 kilo and south Karnataka 24 kilo. The criteria under rice ratio, wheat item distribution level in north Karnataka districts single person 4 kilo as south Karnataka districts. Another three and above person families related 10 kilo in north Karnataka districts 6 kilo in south Karnataka districts. So, these are the two items viz., rice, wheat under the Annabhagya Yojane lowest level of price Rs.1-00 distributed. Sugar distributed under this 
International Journal of Social Science and Economic Research

ISSN: 2455-8834

Volume:05, Issue:11 "November 2020"

scheme. Among all the above mentioned categories, ration cardholders 1 kilo costs Rs.13.50 per kilogram, above all categories equal price and equal price level distributed. The above table shows the results pertaining to quantity and rate of food grains distributed in the state under the Annabhagya Yojana.

Table 2. Details of number of PDS cardholders in Karnataka

\begin{tabular}{|l|l|l|l|l|l|}
\hline \multirow{2}{*}{ Card type } & \multicolumn{5}{|c|}{ No. of Card Holders } \\
\cline { 2 - 6 } & $\mathbf{2 0 1 0 - 1 1}$ & $\mathbf{2 0 1 1 - 1 2}$ & $\mathbf{2 0 1 2 - 1 3}$ & $\mathbf{2 0 1 3 - 1 4}$ & $\mathbf{2 0 1 4 - 1 5}$ \\
\hline AAY & 1128912 & 1199700 & 1118371 & 1100340 & 1117034 \\
\hline BPL & 8504993 & 8401792 & 8715869 & 8486938 & 1017034 \\
\hline APL & 3996511 & 3832931 & 3499056 & 2767627 & 1957100 \\
\hline Total cards in the state & 13630416 & 13434423 & 13333596 & 12454905 & 12299632 \\
\hline
\end{tabular}

Source: Karnataka Economic Survey 2014-15

The above table reveals the details regarding the number of PDS cardholders. A total of 1128912 cardholders are having AAY card type during 2010-11, 1199700 cardholders during 2011-12, 1118371 cardholders during 2012-13, 1100340 during 2013-14 and it was 1117034 AAY cardholders during 2014-15. As in case of BPL cardholders, a total of 8504993 cardholders are having BPL card type during 2010-11, 8401792 cardholders during 2011-12, 8715869 cardholders during 2012-13, 8486938 during 2013-14 and it was 1017034 BPL cardholders during 2014-15 have been identified.

With respect to APL cardholders, a total of 3996511cardholders are having APL card type during 2010-11, 3832931 cardholders during 2011-12, 3499056 cardholders during 2012-13, 2767627during 2013-14 and it was 1957100 APL cardholders during 2014-15 have been recorded in the state of Karnataka.

\section{Merits}

$>\quad$ It is one of the major programme of the Government to eliminate poverty in Karnataka. 
$>\quad$ If the machines are introduced, disqualified ration cards in the State will go out.

To reduce misappropriation of PDS supplies, the machine has made sales conditional to secure identification; PDS beneficiaries access the subsidized goods.

The scheme very much helpful to the poorer.

The machine registers every month all the information about the goods i.e., stock and sold every month and controlled by the Department of Food.

$>\quad$ It will accelerate growth in different sectors.

\section{Problems Faced}

$>\quad$ In some places bogus ration cards are made use and get extra benefits through this, others experience lot in getting the commodities in time.

$>\quad$ PDS suffer from unbalanced and poor quality of food grain from available Fair Price Shops.

$>\quad$ FPSs are not keeping their timings. Information boards are lacking in some places, PDS is not covering all rural and mountainous areas.

$>\quad$ Storage amenities in India are not upto the mark so that foodstuff which is provided to the beneficiaries, is lower quality food grains, adulterated, spoiled or foul smelling.

$>\quad$ Dishonesty in ration shop is based on ration employees and black marketers.

$>\quad$ Lack of administration from apex to lower level.

\section{Suggestions}

$>\quad$ There is a need of the Government to take measures to avoid corruption and leakages.

$>\quad$ Action has to be engaged on defaulters.

$>\quad$ State government should construct more storage god owns so that they can store items for a long time.

There should be clear cut policies about ration cards. All cardholders must be made aware about their rights. 
International Journal of Social Science and Economic Research

ISSN: 2455-8834

Volume:05, Issue:11 "November 2020"

$>$ Observation committees should conduct frequent raids to FPSs.

Social Medias like radio and television should be used to give consciousness to motivate illiterate people and to inform about the benefits that are available under the PDS.

The Karnataka Government must see that it reaches only to the needy section of the society through PDS.

\section{Conclusion}

Targeted Public Distribution System (TPDS), the most important poverty alleviation programmes in India. To sum up the present study on effectiveness of PDS in Karnataka makes clear that most of the people in Karnataka are dependent on agriculture for their daily livelihood. They are not getting income for their hard work, for the reason, depend on PDS. It is the largest food entitlement programme in India. This scheme has to help poor people. However, most of them are deprived from various schemes, that are available. If it is available, quality may not be good.

\section{References}

1. Annual Report of Department of Food and Public Distribution. Ministry of Consumer Affairs, Food and Public Distribution, Government of India.

2. Ghaumaan, Gurdeep Kaur, Dhiman and Pawan Kumar. (2013). Role and effectiveness of PDS in providing food Security. Indian Journal of Research, Vol. 3, Issue 5.

3. Kumar and Parveen. (2010). Food Security: The challenges ahead. Yojana, Vol. 54, pp. 27.

4. Kumar and Velu Suresh. (2010). Security food for All. Yojana, Vol.54, p. 36.

5. Mohanthy and Deepak. (2014). Why is Recent food Inflation in India so persistent?. Southern Economist, Vol. 52, pp. 49.

6. Suresh, K.P. (2015). PDS in Karnataka: Prospects and Challenges of New System. Southern Economist, Vol. 53, pp. 19.

7. Mahalingam.B and Akashraj.D. (2016). Major Drawbacks of Public Distribution System in India-A Review. International Journal for Scientific Research \& Development $\mid$ vol.4, Issue 09, 2016 ISSN (online):2321-0613.pp.602. 
International Journal of Social Science and Economic Research

ISSN: 2455-8834

Volume:05, Issue:11 "November 2020"

8. Gundegowda (2016). "Public Distribution System and Eradication of Poverty", A UGC Sponsored Minor Research Project .p.16. 